\title{
Co-constructing Writing: Handing Over the Reins to Young Authors
}

\author{
Sinead J. Harmey
}

Sinéad Harmey is a Lecturer in Literacy Education in the Department of Learning and Leadership, UCL Institute of Education, 20 Bedford Way, London, WC1H 0AL, United Kingdom; s.harmey@ucl.ac.uk 


\section{Co-constructing Writing: Handing Over the Reins to Young Authors}

'I just can't think of anything that I could write right now' Samantha says as she sits with Anna, her teacher. Samantha is in $4^{\text {th }}$ grade and is attending a literacy tutoring clinic provided by a local university. Her teacher, Anna, is an experienced elementary school teacher, working towards state certification as a reading specialist. As part of the tutoring program, Anna has shared a blank hardback book that they will use to author an authentic text over the course of the ten-week program. Sensing Samantha's difficulty, Anna pushes the book aside and says 'Let me tell you, when people write their books they write about whatever they're interested in. Let's just talk and draw for now' and, with that, they proceed to talk about a princess that Samantha was drawing in a sketch book creating a rich oral narrative about her character. This simple exchange where Anna adjusts instruction after sensing Ally's reluctance provided them both with the opportunity to collaborate as authors, to co-construct ideas to crystallize 'inner thoughts into substance' and communicate 'ideas with other people through interaction and feedback' (Myhill \& Jones, 2009, p.266).

Samantha's parents and class teacher were concerned about her progress in literacy, particularly in writing. Her mother stated that she became anxious when faced with the task of composing in writing, particularly as she moved into higher grades and more was expected of her. This is not an unusual phenomenon. As Quinn and Bingham (2018) argue, 'current policy movement, such as the Common Core State Standards, invoke increasing composing demands' (p. 1).

The purpose of this article is to consider the complexity of the writing process with particular attention to one factor; composition, and to present practical strategies to support 
children to become independent authors. First, I explore the complexity of the writing process and the implications for the teaching of writing with a focus on how observation can be used to guide instruction. Then I describe a study I conducted which used observation as a mechanism to support writing in the context of a literacy practicum for reading specialists working with children from first to sixth grade. In the second half of this article, I describe how observation can be leveraged to support writing, propose strategies to analyze interactions in writing, and share practical strategies to help children to organize their own composition of messages and stories.

\section{Writing is a Complex Process}

Writing is a complex process to define. Rowe and Wilson (2016) described how many teachers and researchers would consider writing from an emergent literacy perspective. From this perspective, writing is viewed as a form of multiple component skills interacting (Quinn \& Bingham, 2018). Writing is viewed as a meaning making activity that stems from a child's ability to represent language in print (Dyson, 1983, p.4). It also has both social and ideational functions (Glasswell, 1999). From this perspective, progress is considered from observations of 'what children can do as writers, regardless of the conventionality of the product' (Rowe \& Wilson, 2016).

Rowe and Wilson (2016) suggested that an alternate perspective is a component skills perspective where attention is devoted to the component cognitive processes involved in writing. Components include, for example; print knowledge, letter-writing, phonological awareness, letter-name knowledge, letter-sound knowledge, spelling, and the linguistic complexity of the written product (see for example, Puranik, Lonigan, \& Kim, 2011). This view of development is best exemplified by the Simple View of Writing (Juel, 1988; Juel, Griffith, \& Gough, 1986). 
From this perspective, writing develops as children gain control of transcription skills (like spelling, letter-writing fluency, handwriting) and language skills like generating and organizing ideas (Kim et al., 2011).

Whatever way one conceptualizes writing, it includes a wide range of skills and processes. Children must organize their thoughts into language (Vygotsky, 1987) and this is dependent on context and motivation. They must then engage in a wide range of complex problem-solving activities to construct this idea in print using knowledge about letters, words, and sentences while simultaneously controlling directional movement and fine motor skills (Author, 2015). For developing writers, a difficulty in any one of the areas described may constrain development. Controlling any one of these factors (articulating an idea to write, for example) would be an achievement.

\section{Which Factors Matter?}

Which factors really matter most? One could argue that all factors matter and contribute uniquely to the development of a complex process. Print knowledge or concepts about print is a predictor of later writing ability (Diamond, Gerde, \& Powell, 2008). Text transcription skills are vitally important and individualized handwriting instruction can contribute to improved text quality and length (Santangelo \& Graham, 2015; Wolf, Abbott, \& Berninger, 2016). Letter naming and letter writing predicts later name writing (Diamond et al., 2008; Milburn et al., 2016). Invented spelling influences conventional spelling and is related to later literacy outcomes (Ouellette \& Senechal, 2017) and spelling difficulties in fourth grade can predict later reading difficulties (Ritchey, Silverman, Schatschneider, \& Speece, 2013). Production of a piece of writing also involves skills like planning, translating, and revising and developing writers can struggle with any of these processes (Limpo, Alves, \& Fidalgo, 2013). Motivation to write 
(attitude to writing and self-efficacy) predicts writing performance (Graham, Kiuhara, Harris, \& Fishman, 2017). Composing is also important with teacher support of composition contributing to stronger writing skills in children (Bingham, Quinn, \& Gerde, 2017). In this article, I will focus specifically on one factor that have been found to be important: namely, composing. I acknowledge that, regardless of how you conceptualize writing, all factors must be orchestrated to write meaningful message.

\section{The Complex act of Teaching Writing}

Why might the teaching of writing be so challenging? In a recent survey, Gilbert and Graham (2010) found that elementary teachers felt underprepared to teach writing, spent little time writing during a typical school day but did report making adaptations for weaker writers. Coker et al. (2016) conducted an observational study of writing instruction practices in US classrooms and found that time spent on writing was limited and focused on skills or writing process instruction.

In a recent study, Bingham et al. (2017) found that students of teachers who focused on composing had better levels of handwriting and invented spelling. Graham and Harris (2016) argued that facilitating composing will result in increased quality of written messages. Given, the complexity of the factors involved in writing some may adopt the stance that it is better to teach transcription skills (like handwriting and spelling) first and that will free up children's cognitive load to compose messages. There is certainly merit to supporting young children to gain control of these skills. However, it is evident that good writing 'involves mastery and simultaneous use of multiple skills' (Gillespie \& Graham, 2014, p. 470). It seems that we cannot afford to adopt a 'first and then' sequence of teaching to writing. While control of transcription skills is essential, there is a danger, particularly for children who struggle with transcription skills, that the 
instructional focus over time may remain fixed on accuracy versus the quality of their written message. For example, Glasswell (1999) found, in a longitudinal study focusing on coconstruction of writing over time that struggling writers were more likely to continue to receive instruction that focused on accuracy compared to average progress writers who had more opportunities to focus on authorial processes of writing. In a sense, proficient writers are more likely to receive instruction as they progressed through school that focuses on ideation (composition and message quality) than their less proficient peers whose instruction revolved around teaching and re-teaching the basics (Glasswell, Parr, \& McNaughton, 2003). While it is essential that teachers differentiate for their students, it is worth considering when might students who struggle with transcription skills have the opportunity to attend to the authorial aspects of writing over time.

\section{Supporting Composition: Donning the Author's Identity}

Johnston (2002), suggests that if we want children to develop a sense of agency in writing then it is essential that we support them to 'don an author's identity' (p. 35). Indeed, Torrance and Galbraith (2006) suggest that writers, of any age, need to acknowledge that writing is a demanding task for even the most skilled author. One of the most demanding aspects of writing is composing - before one commits pen to paper, so to speak. First, one must have a message that one wants to expend the energy to write or that one feels is worth communicating, and then one must find a way to write that message with an audience in mind. As I sit here writing this article, I had many ideas I wanted to communicate to you, the reader. Organizing my thoughts, and committing paper, has arguably been the most challenging aspect of writing and I have composed as I wrote, and rewrote, and rewrote. As Dorothy Parker once said 'It takes me six 
months to do a story. I think it out and write it sentence by sentence - no first draft. I can't write five words but then I change seven' (Temple, 2013)

The task of composing is even more demanding for young children, given the cognitive load involved with the physical act of transcription. Talking about writing, and knowing what one wants to write, can support children with this physical act of transcription (Parr, Jesson, \& McNaughton, 2009). (Author, 2016), in a study that examined differences between children who made typical progress in the context of an early literacy intervention, Reading Recovery, found that they were more likely to experience instruction from teachers who were flexible and encouraged children to change writing topics if the child was not interested. The authors also found that, in this particular study, a hallmark of typical progress was that children exhibited more control of the composition process. Findings from this study also suggested that teachers talked less and could engage in a 'to and fro' in conversation rather than telling the child what to write. Conversely, children who made less progress were more likely to experience conversation where the teacher pursued a topic regardless of children's motivation to write about the topic. Perhaps, as Parr et al. suggested, the 'talk (as a platform for writing)' helped the 'children to refine the strategic processes of planning, revision, encoding, and monitoring by making explicit the implicit in writing' (p. 432).

\section{Supporting Composition: Using Observation to Guide Writing Interactions}

Given the importance of composing, it is important that teachers, particularly, those who work with developing writers assess and observe children's ability to compose as they write. This can be challenging given that often, we judge progress in writing on what children write versus how they write. Indeed, Quinn and Bingham (2018) found that, in the field of writing assessment, we know more about how to assess transcription skills than composition skills. 
Certainly, while we can infer from a written product the quality of a child's composition and whether they revised, this is particularly challenging as they may not reveal what they can do in writing if they find spelling or transcribing hard. For example, a child may have composed a message easily and fixed two or three errors as they wrote but this will not be revealed if I, as a teacher, judge their progress on what they wrote alone. Indeed, Graham, Hebert, Paige Sandbank, and Harris (2014) found that it is incredibly hard to get a reliable estimate of young struggling writers' ability without collecting multiple writing samples and that writing ability in any one genre did not predict ability in another genre, As Poehner and Lantolf (2010) argued; independent tasks may not be sufficient in helping tutors understand ability.

What alternate modes of assessment can teachers use? While assessment can often be conflated with tests they are quite different terms. A test is the tool we use whereas an assessment is the action of making a judgement about something (Merriam-Webster, 2018)? If we view teaching and assessment as dynamic and interactive processes the observation and immediate actions taken on these judgements in the context of teaching interactions are a fruitful place to start. I suggest that, that given the complexity of writing that an 'observe, assess, and take action' stance might provide a fruitful way of supporting young writers learning. If teachers sensitively observe what the child controls, make an in the moment decision, they can simultaneously guide interactions such that the child is provided with opportunities to initiate problem solve the task of writing (Clay, 2001, p.16).

In the next section, I take this idea of observation as a means to support composition forward using vignettes from my research. These ideas stem from a study where I (Author, 2017) researched the teaching of writing in the context of a ten-week one-to-one literacy tutoring clinic in a university in the United States. The participants included 12 teachers, studying towards a 
MS. Ed in Literacy, who worked individually with 12 children aged 6 to 12 years of age. The aims of the study were to; (a) to investigate how literacy teachers integrated authentic authoring experiences into lessons, (b) to describe how teachers could support children to compose authentic messages through observation and (c) to examine interactions between teacher beliefs about writing and types of support provided. In this article I focus on the first two elements of the study.

At the beginning of the study, interviews and surveys were conducted to ascertain teachers' experiences of teaching and theoretical orientations to the teaching of reading (DeFord, 1985) and writing (Graham, Harris, MacArthur, \& Fink-Chorzempa, 2002). These surveys can be used to ascertain teachers' theoretical orientations and pedagogical approaches to the teaching of reading and writing respectively. In the fourth week of the study, workshops were introduced following each tutoring session where the author (the instructor) and the participants worked to implement practical strategies to support writing instruction. Teachers assessed children's writing using the Test of Early Written Language-3 (Hresko, Herron, Peak, \& Hicks, 2012) at the beginning and end of the programme as well as conducting writing observations during the programme. Videos of teacher-student dyads were collected at four points in time during the programme and interactions were coded following the completion of the programme to ascertain the nature of teacher support during writing and whether it changed over time.

The surveys and interviews revealed that candidates espoused a process approach to writing (cf. Graves, 1983; Calkins, 2013) and that they felt challenged when catering for children who found writing difficult. Analysis of the first round of videos (all taken before the fourth week of tutoring) revealed that teachers often focused on transcription skills (for example, spelling and punctuation). Teachers often neglected to or struggled, however, to adjust teaching 
of composing (of the message) and revision processes. In other words, teachers often maintained control of these aspects of writing and acted as both composer and editor for the child. Video analysis of later lessons and interviews at the end of the programme suggested that teacher candidates did take up some of the strategies and were more likely to self-reflect on their actions in the teaching and learning context. Based on the strategies implemented in this study I describe how composition can be observed and assessed and propose actions that might prove useful to the intervention teacher.

\section{Supporting Independence in Composing: Implications for Teaching}

\section{Observing and Reflection on Conversations}

So, what can teachers do to support composition in writing? In this section, I consider practical strategies to support conversations surrounding composition in writing. The teachers in the study used a rubric (see Author, 2017) to guide observations mid-way through the tutoring programme. Teachers took time to observe the children writing by asking the child to write what they could and by providing help only if needed (if they stalled or appealed). The rubric was used to support teachers as a framework for considering how a child used knowledge about letters and words. It also was used to prompt teachers to look for observable behaviors that might infer that the child was actively monitoring his or her own writing, including his or her composition of the message. Foci for reflection included the following;

- Was the child told what to write?

- Did the child need a lot of support to compose a message?

- Did the child exhibit control of parts of the conversation?

- Could the child expand the message or story with support?

- Was the child in control of the conversation and eager to write? 
- Based on your reflection consider what makes it hard (or indeed easy) for the child to compose?

- Do you think the difficulty is related to topic or interest?

Teachers took notes as they taught and completed the rubric as a tool for self-reflection and worked to consider what prompts might be helpful in the future. Anna, the teacher we met earlier in the article, wrote in her lesson reflection on week five:

Samantha is more in control of what she wants to write and today she came to the lesson eager to develop her story. She was able to expand on some key ideas and used words like 'I would like to add this' and 'I don't want to spend too much time talking about him (one of the characters). When she seemed hesitant, I tried to reinforce that these were all choices she could make as she was the author and to try to reflect on why those decisions might be a good idea. It was interesting trying to take a neutral stance and just let her at it (Tutoring Session 5, Anna's reflection on lesson).

Taking the time to observe how a child writes can supplement the collection of writing samples that are commonly used to track writing progress. The notes captured actions (on both the teachers and child's part) that were contributing to the co-construction of the written message. Taking an observational stance helped Anna reflect on simple actions she could take (adopting a neutral stance to give Samantha a chance to reflect on how she could make authorial choices and their implications). Although this occurred in a tutoring setting, in the general classroom setting, it would be useful to find an opportunity to observe a young learner in conversations before writing in class or in groups. This could be done by adopting a neutral stance as children work in independent settings and by using the guiding questions to guide your observations.

\section{Talk to Support Composing}


Clay (2016) suggests that writing could revolve around 'anything that interests the child' but that teachers need to 'give some thought to how' children will compose (p. 55). There are infinite number of ways teachers can invite children's participation in a conversation. An interesting study by MacKenzie (2011) shifted the focus in classrooms from drawing and talking before writing. So often we only 'allow' children to draw once they've written. She found that drawing allowed children to represent their ideas and thoughts and was supportive of the composing process and overall writing progress.

If conversation about writing is difficult it could be useful to consider patterns of interaction. Who is doing the talking? Is the child struggling to compose full sentences? Aside from considering interest in terms of topic it is useful to consider how we use language to support composing. As Clay (1991) wrote,

"if the child's language development seems to be lagging, it is misplaced sympathy to do his talking for him. Instead, put your ear closer, concentrate more sharply, smile more rewardingly, and spend more time in genuine conversation, difficult though it is (Clay, 1991, p.69)

In my study, I found that teachers often would revert to taking a questioning stance during conversations if children were reluctant to contribute. The conversations began to echo the 'tug-of-war' described by Fullerton and DeFord (2001) in a study of teacher-student interaction in writing in the context of Reading Recovery., a first grade intervention. Because of this, and building on the work of Fullerton and DeFord, I have used the categories of talk described by Fullerton and DeFord to code talk in interactions between students and teachers in a range of grades. These codes have been useful in other professional development workshops with teachers to help teachers to think about changing interaction patterns to support children to 
talk about their messages (see Table 1). Using excerpts of teacher-student interactions, and Fullerton and DeFord's codes I have coded types of teacher talk that might move away from a questioning to a more conversational stance. The excerpts below are examples of coded transcripts with notes on reflections about why this type of talk might be more productive. 
Table 1

Fullerton and DeFord's (2001) Categories of Child-Teacher Talk: Examples

\begin{tabular}{|c|c|}
\hline $\begin{array}{l}\text { Category of Talk: } \\
\text { Composing }\end{array}$ & Example \\
\hline Initiate an idea & $\begin{array}{l}\text { Teacher: Last week you wrote about Einstein's life as a boy. What can } \\
\text { you tell me about when he went to college? } \\
\text { Teacher: In the book, you read about Jackie's Robinson's life. What was } \\
\text { the bit that surprised you the most? } \\
\text { Note: } \\
\text { In these excerpts the tutors initiate ideas using their thoughts as a platform } \\
\text { to start the conversation. }\end{array}$ \\
\hline Clarify & $\begin{array}{l}\text { Teacher: So, I guess what you're saying is that he did not like school. Is } \\
\text { that it? } \\
\text { Note: } \\
\text { The teacher repeats what she heard to see if this is what they child meant } \\
\text { versus asking further 'What, why, how questions'. }\end{array}$ \\
\hline Expand & $\begin{array}{l}\text { Teacher: And tell me a little bit more about what else you know. } \\
\text { Note: } \\
\text { This is a positive way to ask the child to expand because it assumes they } \\
\text { are the expert and gently encourages them to tell 'a little bit more'. }\end{array}$ \\
\hline Repeat & $\begin{array}{l}\text { Repeat what the child says } \\
\text { Note: } \\
\text { It helps them to hear their contribution again. }\end{array}$ \\
\hline Rephrase & $\begin{array}{l}\text { Child: We was walking very fast down the hall - we no want him to catch } \\
\text { you. } \\
\text { Teacher: Ah - ok so you were walking down the hall and you did not } \\
\text { want him to catch you. } \\
\text { Note: } \\
\text { In this exchange, the teacher rephrases what the child said. This shows } \\
\text { acceptance of the child's idea and yet allow him to hear his ideas phrased } \\
\text { in a grammatically acceptable way (see Clay, 2015). }\end{array}$ \\
\hline Paraphrase & $\begin{array}{l}\text { Child: and then we went in the car and then we drove to the hotel and then } \\
\text { we reached the hotel and my mom went to the desk and then my dad took } \\
\text { the bags out of the car. }\end{array}$ \\
\hline
\end{tabular}




\begin{tabular}{|l|l|}
\hline $\begin{array}{l}\text { Teacher: Ah. So, you drove in the car to the hotel. Then when you } \\
\text { reached the hotel your mom went to check in and your dad took the bags } \\
\text { out of the car. }\end{array}$ \\
$\begin{array}{l}\text { Note: } \\
\text { In this exchange, the teacher tries to paraphrase what the child offered in } \\
\text { conversation into more grammatically acceptable sentences. She assumes } \\
\text { responsibility to model what this might look like. }\end{array}$ \\
\hline
\end{tabular}

The examples demonstrate how teachers might work towards a more genuine conversational stance when working with children to compose. The last example demonstrates a 'stream of consciousness' like contribution from the child. Indeed, one of the findings from my study was that some children could talk very freely and had lots of ideas but teachers found it hard to support children to 'shape' these ideas into written form. One teacher, reflected 'I love that he comes to the writing part of the lesson with lots of ideas - what's hard is helping him to organize his thoughts' (Joanna, Reflection, Week 2). In other words, the sticking point happened when children tried to organize their thoughts to write. Paraphrasing, as demonstrated in table 1, what a child says honors their message but helps them formulate the message into shorter sentences which may be easier to write. The types of talk identified here could be used in coaching situations to analyze transcripts or short vignettes from teaching of writing.

\section{Supporting Children to Organize Their Thoughts}

Another strategy that we used during the literacy practicum to support children's composing was based on ideas from Angela Stockman's (2015) book 'Make Writing'. Using Stockman's book we explored the use of post-it notes to support children to compose longer narratives. Younger children, drawing on MacKenzie's (2011) study about the utility of drawing before writing, drew pictures on post-its and then organized the pictures to tell the story. Older children, wrote over extended periods using the post-it notes to help them organize and 
reorganize their stories. This strategy proved very successful with the older writers in the programme. As Robert, a sixth grader reflected in an evaluation at the end of the programme; ' $I$ liked the post-it's - they helped me keep my ideas together and change things to make a better story without having to use an eraser.... I didn't get tired of it'. In Figure 1 samples are provided from two children; Alan, a fifth grader, worked to compose a book that combined fact and fiction and Angela, a second grader, worked to compose a short story. 
Figure 1

Planning for Writing Using Post-It Notes

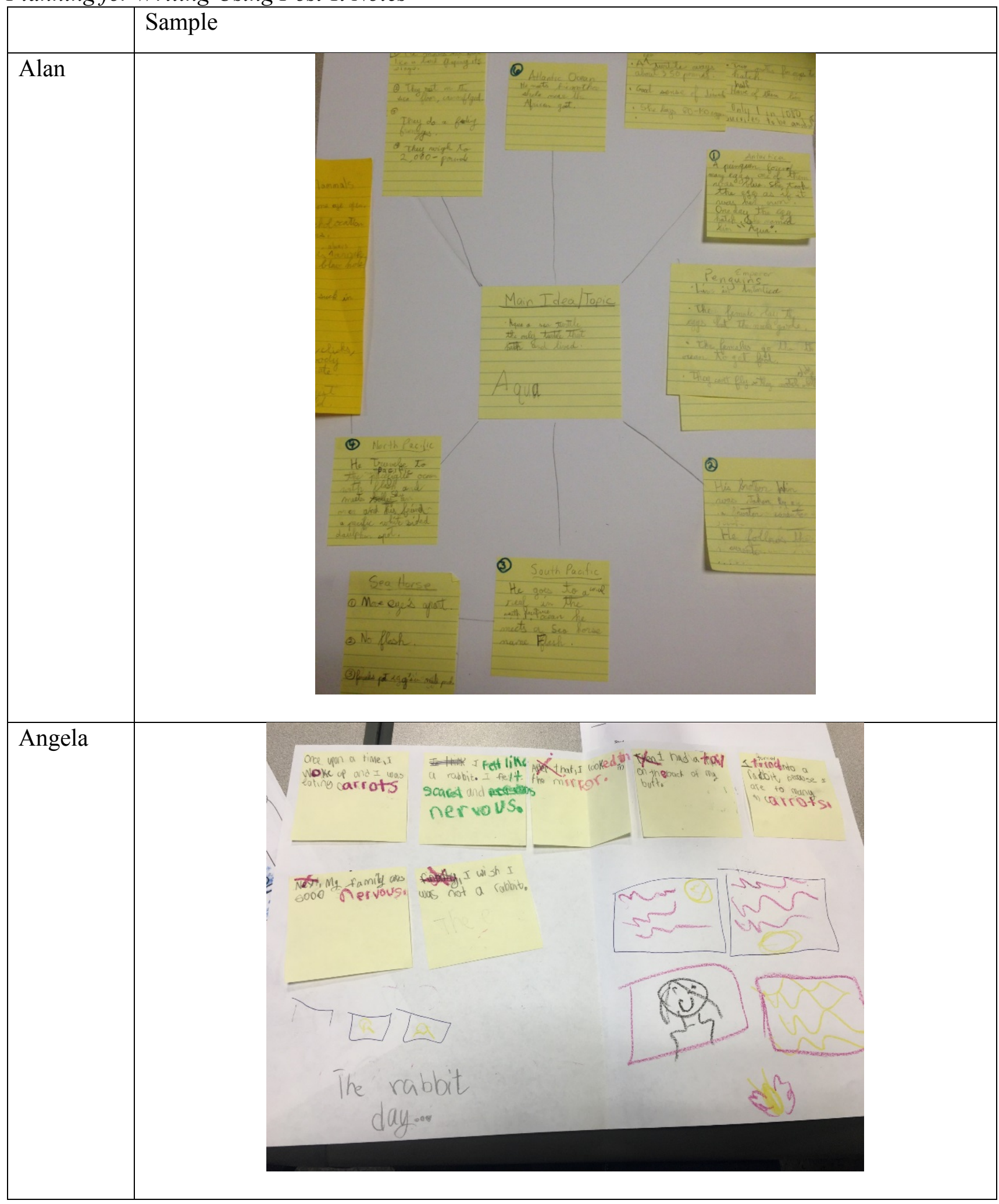


The benefit of using post-it notes, as can be seen in Table 2 , is that it gave the child the opportunity to 'tinker' (Stockman, 2015) and compose in a non-linear manner, as is typically the case for more accomplished writers. The child can move back and forth through ideas, play with order, and use a variety of modes. Angela, for example, used the post-it's to organize and revise her story.

\section{Conclusion}

Writing is a challenging endeavor, even for the most skilled writer. In today's classrooms, teachers have a challenging task to support children to produce the types of texts expected of them by curricular benchmarks. Knowing what and how to teach is a challenge. In this paper, I have focused on one element of the writing process, composing, and reflected on some key strategies that might support teachers to hand over the reins of control to young writers.

\section{References}

Author (2015)

Author (2016) 
Author (2017)

Bingham, G.E., Quinn, M.F., Gerde, H.K. (2017). Examining early childhood teachers’ writing practices: Associations between pedagogical supports and children's writing skills. Early Childhood Research Quarterly, 39, 35 - 46. https://doi.org/10.1016/j.ecresq.2017.01.002

Calkins, L. (2013). Writing pathways: Performance assessments and learning progressions, Grades K-8. Portsmouth, N.H: Heinemann.

Clay, M.M. (1991). Becoming literate: The construction of inner control. Portsmouth, NH: Heinemann.

Clay, M.M. (2001). Change over time in children's literacy development. Auckland. NZ: Heinemann Educational Books.

Clay, M.M. (2016). Literacy lessons designed for individuals. Portsmouth, NH: Heinemann.

Coker, D., Jr., Farley-Ripple, E., Jackson, A., Wen, H., MacArthur, C., \& Jennings, A. (2016). Writing instruction in first grade: An observational study. Reading and Writing, 29, 793832. http://dx.doi.org/10.1007/s11145-015-9596-6

DeFord, D. (1985). Validating the construct of theoretical orientation in reading. Reading Research Quarterly, 20: 351-367. https://doi.org/10.2307/748023

Dyson, A. H. (1983). The emergence of visible language: Interrelationships between drawing and early writing. Visible Language, 16, 360-381.

Diamond, K. E., Gerde, H. K., \& Powell, D. R. (2008). Development in early literacy skills during the pre-kindergarten year in Head Start: Relations between growth in children's writing and understanding of letters. Early Childhood Research Quarterly, 23(4), 467478. DOI: 10.1016/j.ecresq.2008.05.002

Fullerton, S., \& DeFord, D. (2001). Conversations before writing during Reading Recovery: 
Negotiations or tug of war? National Reading Conference Yearbook, 50, 213-227.

Gadd, M. \& Parr, J.M. (2017). Practices of effective writing teachers. Reading and Writing, 30, 1551 - 1574. https://doi.org/10.1007/s11145-017-9737-1

Gilbert, J. \& Graham, S. (2010). Teaching writing to elementary students in grades 4-6: A national survey. The Elementary School Journal, 110, 495 - 518.

Gillespie, A., \& Graham, S., (2014). A meta-analysis of writing interventions for students with learning disabilities. Exceptional Children, 80, 454 - 473. https://doi.org/10.1177/0014402914527238

Glasswell, K. (1999). The patterning of difference: Teachers and children constructing development in writing (Unpublished doctoral dissertation). University of Auckland, New Zealand.

Glasswell, K., Parr, J.M., McNaughton, S. (2003). Four ways to work against yourself when conferencing with struggling writers. Language Arts, 80, 291 - 298.

Graham, S., Kiuhara, S. A., Harris, K. R., \& Fishman, E. J. (2017). The relationship among strategic writing behavior, writing motivation, and writing performance with young, developing writers. Elementary School Journal, 118(1), 82-104. DOI: 10.1086/693009

Graham, S., \& Harris, K.R. (2000). The role of self-regulation and transcription skills in writing and writing development. Educational Psychologist, 35, 3-12. https://doi.org/10.1207/S15326985EP3501_2

Graham, S., \& Harris, K. R. (2016). A Path to Better Writing: Evidence-Based Practices in the Classroom. Reading Teacher, 69(4), 359-365. DOI: 10.1002/trtr.1432 
Graham, S., Harris, K.R., MacArthur, C., \& Fink-Chorzempa, B. (2003). Primary grade teachers' instructional adaptations for weaker writers: A national survey. Journal of Educational Psychology, 95, 279—293. https://doi.org/10.1037/0022-0663.95.2.279

Graham, S., Hebert, M., Paige Sandbank, M., \& Harris, K. R. (2014). Assessing the writing achievement of young struggling writers: Application of generalizability theory. Learning Disability Quarterly, 39(2), 72-82. DOI: 10.1177/0731948714555019.

Graves, D. (1983). Writing: Teachers and children at work. Portsmouth, NH: Heinemann. Hayes J.R. (2004) What Triggers Revision?. In: Allal L., Chanquoy L., Largy P. (eds) Revision Cognitive and Instructional Processes. Studies in Writing, vol 13. Springer, Dordrecht. https://doi.org/10.1007/978-94-007-1048-1_2

Hresko, W.P., Herron, S.R., Peak, P.R., \& Hicks, D.L. (2012). The test of early written languge, third edition (TEWL-3). San Antonio, TX: Pearson

Johnston, P. (2002). Choice words: How language affects children's learning. Stenhouse Publishers.

Juel, C. (1988). Learning to read and write: a longitudinal study of 54 children from first through fourth grades. Journal of Educational Psychology, 80, 437-447. https://doi.org/10.1037/0022-0663.80.4.437

Juel, C., Griffith, P.L. \& Gough, P.B. (1985). Reading and spelling strategies of first grade children. In J. A. Niles \& R. Lalik (Eds.), Issues in Literacy: A research perspective (pp. 306-309). Rochester, NY: National Reading Conference.

Kim, Y.-S., Al Otaiba, S., Puranik, C., Sidler, J. F., Gruelich, L., \& Wagner, R. K. (2011). Componential skills of beginning writing: An exploratory study at the end of 
kindergarten. Learning and Individual Differences, 21, 517-525.

https://doi.org/10.1016/j.lindif.2011.06.004

Limpo, T., Alves, R,A., \& Fidalgo, R., (2013). Children's high-level writing skills: Development of planning and revision and their contribution to writing quality. British Journal of Educational Psychology, 84.

MacKenzie, N. (2011). From drawing to writing: What happens when you shift teaching priorities in the first six months of school. Austalian Journal of Language and Literacy, $34,322-340$.

Merriam-Webster (2018). https://www.merriam-webster.com/dictionary/assessment

Myhill, D. \& Jones, S. (2009). How talk becomes text: Investigating the concept of oral rehearsal in early years' classrooms. British Journal of Educational Studies, 57, 265-284. DOI: 10.1111/j.1467-8527.2009.00438.x

Ouellette, G., \& Sénéchal, M. (2017). Invented spelling in kindergarten as a predictor of reading and spelling in Grade 1: A new pathway to literacy, or just the same road, less known? Developmental Psychology, 53(1), 77-88. http://dx.doi.org/10.1037/dev0000179

Parr, J., Jesson, R. and McNaughton, S. (2009) Agency and platform: The relationships between talk and writing. In R. Beard, D. Myhill, J. Riley \& M. Nystrand (Eds.), The Sage handbook of writing development (pp. 246-259). London: Sage. https://doi.org/10.4135/9780857021069.n17

Poehner, M.E. \& Lantolf, J.P.,(2010).Vygotsky's Teaching-Assessment Dialectic and L2 Education: The Case for Dynamic Assessment. Mind, Culture, and Activity, 17, 312 330. https://doi.org/10.1080/10749030903338509

Ritchey, K.D., Silverman, R.D., Schatschneider, C., Speece, D.L. (2013). Prediction and stability 
of reading problems in middle childhood. Journal of Learning Disabilities, 48, 298 -309. https://doi.org/10.1177/0022219413498116

Rowe, D. \& Wilson, S. (2016). The development of a measure of early childhood writing: Results from the Write Start! Writing assessment. Journal of Literacy Research, 47, 245292. doi: $10.1177 / 1086296 \times 15619723$

Santangelo, T., \& Graham, S. (2015). A Comprehensive Meta-analysis of Handwriting Instruction. Educational Psychology Review. DOI: 10.1007/s10648-015-9335-1

Stockman, A. (2015). Make writing: 5 teaching strategies that turn writer's workshop into a maker space. Times 10 Publications

Temple, E. (2013). 'My pencils outlast their erasers: great writers and the art of revision'. The Atlantic. Retrieved from https://www.theatlantic.com/entertainment/archive/2013/01/mypencils-outlast-their-erasers-great-writers-on-the-art-of-revision/267011/

Torrance, M., \& Galbraith, D. (2006). The Processing Demands of Writing. In C. A. MacArthur, S. Graham, \& J. Fitzgerald (Eds.), Handbook of writing research (pp. 67-80). New York, NY, US: Guilford Press.

Wolf, B., Abbott, R.D., \& Berninger, V.W. (2016). Effective beginning handwriting instruction; multi-modal, consistent format for 2 years, and linked to spelling and composing. Reading and Writing, 30, 299 - 317. DOI: https://doi.org/10.1007/s11145-016-9674-4

Vygotsky, L. S. (1987). Thinking and speech. In R.W. Rieber \& A.S. Carton (Eds.), The collected works of L.S. Vygotsky, Volume 1: Problems of general psychology (pp. 39285). New York: Plenum Press. (Original work published 1934.) 
HANDING OVER THE REINS 